\title{
Pharmacological effects of Picrasma quassioides (D. Don) Benn for inflammation, cancer and neuroprotection (Review)
}

\author{
JAIHYUNG LEE ${ }^{1,2^{*}}$, YI-XI GONG ${ }^{3 *}$, HYUNJEONG JEONG ${ }^{1,2}$, HOYOUNG SEO ${ }^{1,2}$, \\ DAN-PING XIE ${ }^{3}$, HU-NAN SUN ${ }^{3}$ and TAEHO KWON ${ }^{4}$ \\ ${ }^{1}$ Epigenetics Drug Discovery Center, Hwalmyeong Convalescence Hospital, Gapyeong, Gyeonggi 12458; \\ ${ }^{2}$ Korean Convergence Medicine Center, Hwalmyeong Hospital of Korean Medicine, Seoul 03790, Republic of Korea; \\ ${ }^{3}$ College of Life Science and Technology, Heilongjiang Bayi Agricultural University, Daqing, Heilongjiang 163319, \\ P.R. China; ${ }^{4}$ Primate Resources Center, Korea Research Institute of Bioscience and \\ Biotechnology, Jeongeup-si, Jeonbuk 56216, Republic of Korea
}

Received May 14, 2021; Accepted August 25, 2021

DOI: $10.3892 / \mathrm{etm} .2021 .10792$

\begin{abstract}
Picrasma quassioides (D. Don) Benn is an Asian shrub with a considerable history of traditional medicinal use. $P$. quassioides and its extracts exhibit good therapeutic properties against several diseases, including anti-inflammatory, antibacterial and anticancer effects. However, the composition of compounds contained in $P$. quassioides is complex; although various studies have examined mixtures or individual compounds extracted from it, studies on the application of $P$. quassioides extracts remain limited. In the present review, the structures and functions of the compounds identified from $P$. quassioides and their utility in anti-inflammatory, anticancer and neuroprotectant therapies was discussed. The present review provided up-to-date information on pharmacological activities and clinical applications for $P$. quassioides extracts.
\end{abstract}

\section{Contents}

1. Introduction

2. Active components of Picrasma quassioides (D. Don) Benn

Correspondence to: Dr Taeho Kwon, Primate Resources Center, Korea Research Institute of Bioscience and Biotechnology, 351-33 Neongme-gil, Ibam-myeon, Jeongeup-si, Jeonbuk 56216, Republic of Korea

E-mail: kwon@kribb.re.kr

Dr Hu-Nan Sun, College of Life Science and Technology, Heilongjiang Bayi Agricultural University, 2 Xinyanglu, Daqing, Heilongjiang 163319, P.R. China

E-mail: sunhunan76@163.com

${ }^{*}$ Contributed equally

Key words: Picrasma quassioides (D. Don) Benn, alkaloid, $\beta$-carboline, carthinone, bis- $\beta$-carboline, quassinoids, triterpenoids
3. Anti-inflammatory role of Picrasma quassioides (D. Don) Benn

4. Anticancer role of Picrasma quassioides (D. Don) Benn

5. Neuroinflammatory role of Picrasma quassioides (D. Don) Benn

6. Clinical applications and developmental prospects of Picrasma quassioides (D. Don) Benn

7. Conclusions

\section{Introduction}

Picrasma quassioides (D. Don) Benn is a perennial herbaceous plant of the Simaroubaceae DC family that grows in Korea, China, Japan and Nepal. P. quassioides is a widely used Asian traditional medicine and is officially recorded in the Korea and Chinese Pharmacopoeia (ed. 2020) (1). The dried branches and leaves of $P$.quassioides may be ingested or used as an externally applied medicine. According to concepts of Korean/Asian medicine, the $P$. quassioides flavor is bitter and cold with little poison, and the meridian tropism involves the lung and large intestine. The functions and indications for use include 'removing heat or dampness' (concepts of Korean/Asian medicine) and detoxification. Thus, this Asian traditional medicine may be used for wind-heat cold (treatments aimed at expelling out heat and cooling the body), sore throat, diarrhea and eczema (2). P. quassioides is also used to treat rabies and snake bite (3).

The stem of $P$.quassioides is a thick cylinder that may range from 4 to $30 \mathrm{~cm}$ in diameter. The surface is brown and has a fine longitudinal texture, and the lenticel is raised, light-brown and round or rhomboid in shape. The stem is pale yellow, dark toward the middle with clear rings in its cross-section and has a bitter taste. The branches are cylindrical with a diameter of $0.5-15 \mathrm{~cm}$, with a dark brown or reddish-brown surface, longitudinal stripes, and spotty and slightly raised, light-brown lenticels. The cross-section is pale yellow, with myelination in the middle, and the taste is bitter. The roots are cylindrical with a diameter of $3-8 \mathrm{~cm}$. Their surface is gray-brown with gray-brown longitudinal cracks and the pores are not obvious. 
The cross-section is pale-yellow and the root has an overall bitter taste (4). Collectively, the entire P. quassioides plant is of substantial medicinal value. The root is removed in autumn and winter along with the young branches and the rough external skin is scraped off. The branches and trunks are dried, cleaned and sliced; the leaves may be washed with clean water and cut into pieces. The dried branches and leaves are stored and used for medicinal purposes $(5,6)$.

\section{Active components of Picrasma quassioides (D. Don) Benn}

The chemical composition of $P$. quassioides is complex. Studies have identified the active components by separating and purifying the plant parts according to the structure and organic reaction characteristics following different extraction processes to obtain a variety of compounds. After nuclear magnetic resonance mass spectrometric analysis, experiments including cell-based assays, determination of GAPDH activity and others are used to test the properties of the extracted compounds. Previous studies separated and extracted the major components and confirmed that they are $\beta$-carboline alkaloids, carthinone alkaloids, bis- $\beta$-carboline alkaloids, quassinoids and triterpenoids (7-10).

$\beta$-carboline alkaloids. Although most $\beta$-carboline alkaloids are extracted from natural plants, a small number of them have been synthesized chemically. $\beta$-carboline alkaloids have a planar tricyclic ring system consisting of indolopyridine carboline rings. These $\beta$-carboline alkaloids are the most representative alkaloids in $P$. quassioides. This alkaloid type has various chemical structures and a wide range of biological activities. A total of $38 \beta$-carboline alkaloids have been isolated from $P$. quassioides (compounds 1-38). The structures and names of these compounds are presented in Figs. 1-3 and Table I and Fig. S1.

Carthinone alkaloids. Similar to $\beta$-carboline alkaloids, carthinone alkaloids are polycyclic compounds containing a carboline ring. The entire molecule is a highly conjugated system. All carthinone types share a common canthin-6-one backbone, i.e., the basic structure is based on a canthin-6-one backbone. A total of 12 carthinone alkaloids were isolated from $P$. quassioides (compounds 39-50). The structures and names of these compounds are presented in Fig. 4 and Table II and Fig. S1.

Bis- $\beta$-carboline alkaloids. Bis- $\beta$-carboline alkaloids are bimolecular compounds formed by two indole alkaloids joined by chemical bonds. These compounds are important alkaloid components in Picrasma BL species and may have biological activities similar to those of $\beta$-carboline alkaloids. A total of 10 bis- $\beta$-carboline alkaloids have been isolated from $P$. quassioides (compounds 51-60). The structures and names of these compounds are presented in Figs. 5 and 6, Table III and Fig. S1.

Quassinoids. Quassinoids are characteristic components of Simaroubaceae DC species, and its parent nuclear structure is mainly composed of nigakihemiacetal and nigakilactone. A total of 45 quassinoids have been isolated from $P$. quassioides (compounds 61-105); their names structures are presented in Figs. 7-9 and Table IV and Fig. S1.

Triterpenoids. Although triterpenoids account for a small proportion of the active compounds in P. quassioides, these molecules have anti-inflammatory and anticancer effects. A total of eight triterpenoids have been isolated from P. quassioides (compounds 106-113). The structures of these compounds are presented in Fig. 10 and Table V and Fig. S1.

\section{Anti-inflammatory role of Picrasma quassioides (D. Don) Benn}

$P$. quassioides is a plant with effective anti-inflammatory action that has been used for numerous years in Asian traditional medicine. While previous studies have investigated the anti-inflammatory effects of $P$. quassioides, the underlying molecular mechanisms have remained elusive. Inflammation is a defensive response produced by local tissues to external stimulation (11). However, excessive, persistent inflammatory reactions lead to physical and pathological damage and may eventually lead to the development of several diseases such as asthma (12), diabetes (13), hypertension (14), rheumatoid arthritis (15) and arteriosclerosis (16). Lipopolysaccharide (LPS) is an inflammatory activator that binds to toll-like receptor 4 in macrophages (17), activating nuclear factor- $\kappa \mathrm{B}$ $(\mathrm{NF}-\kappa \mathrm{B})$ (18) and mitogen-activated protein kinase (MAPK) (19). These two signaling pathways cause the release of inflammatory factors (20), thereby regulating oxidative stress responses and accelerating inflammatory responses, which may cause changes in inflammatory proteins (21). In particular, inflammation induces the protein degradation of the recombinant inhibitory subunit of $\mathrm{NF}-\kappa \mathrm{B} \alpha$, MAPK-related protein phosphorylation, increased inducible nitric oxide (NO) synthase (iNOS) and cyclooxygenase-2 (COX-2) protein expression and release of inflammatory mediators such as NO, tumor necrosis factor $\alpha$ (TNF- $\alpha$ ) and interleukin (IL)-6 (Table VI) (22).

NO is an important inflammatory factor. Therefore, inhibiting NO production is an effective method for treating and preventing inflammation-related diseases. TNF- $\alpha$ is a polypeptide cytokine that regulates other inflammatory factors and proteases, thereby regulating inflammation (23). IL-6 is another circulating cytokine that regulates immune cell activation, $\mathrm{T}$ and $\mathrm{B}$ cell proliferation and differentiation, as well as inflammatory responses (24). Of note, ILs are divided into proinflammatory (IL-1, -6 and -8 ) and anti-inflammatory (IL-4 and -10) factors. COX, also called prostaglandin $\mathrm{G} / \mathrm{H}$ synthase, has two isoforms, COX-1 and COX-2, which have key roles in inflammation and are targeted by nonsteroidal anti-inflammatory drugs (25).

P. quassioides extracts effectively inhibited ovalbumin-induced allergic asthma in mice. In vitro experiments suggested that $P$. quassioides extracts have an anti-inflammatory role by reducing IL-4, IL-5, IL-13, immunoglobulin E and iNOS expression (26). Methanolic extracts of $P$. quassioides suppressed iNOS and COX-2 expression by inhibiting NF- $\mathrm{NB}$ activity and reducing ERK phosphorylation to achieve anti-inflammatory effects in vitro (27). Similarly, 
<smiles>OCc1nccc2c1[nH]c1ccccc12</smiles><smiles>O=Cc1nccc2c1[nH]c1ccccc12</smiles><smiles>C=Cc1ncc(OC)c2c1[nH]c1c(OC)cccc12</smiles>

5<smiles>CC(=O)c1ncc(O)c2c1[nH]c1ccccc12</smiles><smiles>O=Cc1ncc(O)c2c1[nH]c1ccccc12</smiles><smiles>COc1nccc2c1[nH]c1ccccc12</smiles>

10<smiles>COCCc1ncc(OC)c2c1[nH]c1c(OC)cccc12</smiles>

14<smiles>CC(=O)c1nccc2c1[nH]c1ccccc12</smiles><smiles>CC(=O)CCc1nccc2c1[nH]c1ccccc12</smiles>

7<smiles>O=C(O)c1nccc2c1[nH]c1ccccc12</smiles>

11<smiles>CCc1ncc(OC)c2c1[nH]c1c(O)cccc12</smiles>

15<smiles>CCOC(=O)c1nccc2c1[nH]c1ccccc12</smiles><smiles>O=Cc1ncc(O)c2c1[nH]c1ccccc12</smiles>

8<smiles>CC(=O)c1nccc2c1[nH]c1ccccc12</smiles>

12<smiles>C=Cc1ncc(OC)c2c1[nH]c1c(O)cccc12</smiles>

16

Figure 1. Structure of $\beta$-carboline alkaloids (1). Chemical formula of compounds 1-16 and the corresponding names: 1) 1-hydroxymethyl- $\beta$-carboline, 2) 1-formyl- $\beta$-carboline, 3) 1-methoxyformacyl- $\beta$-carboline, 4) 1-ethoxyformyl- $\beta$-carboline, 5) 1-vinyl-4,8-dimethoxy- $\beta$-carboline, 6$) 1$-formyl-4-methoxy- $\beta$ carboline, 7) 1-methoxypropionyl- $\beta$-carboline, 8) 1-formyl-4-hydroxy- $\beta$-carboline, 9) 1-methoxyformacyl-4-hydroxy- $\beta$-carboline, 10) 1-methoxyl- $\beta$-carboline, 11) $\beta$-carboline-1-methanoic acid, 12) 1-ethanoyl- $\beta$-carboline, 13$)$ 1-ethyl-4,8-dimethoxy- $\beta$-carboline, 14$) 1$-(2-methoxyl)-ethyl-4,8-dimethoxyl- $\beta$-carboline, 15) 1-ethyl-4-methoxyl-8-hydroxy- $\beta$-carboline and 16) 1-vinyl-4-methoxyl-8-hydroxy- $\beta$-carboline.<smiles>CCN(CC)CCc1ncc(OC)c2c1[nH]c1c(O)cccc12</smiles>

17<smiles>COc1cccc2c1[nH]c1c(C(=O)CC(C)=O)ncc(OC)c12</smiles>

21<smiles>O=C(O)C(O)C(O)c1nccc2c1[nH]c1ccccc12</smiles>

25<smiles>CCc1ncc(OC)c2c1[nH]c1ccccc12</smiles>

18<smiles>O=C(O)CCc1nccc2c1[nH]c1ccccc12</smiles>

22<smiles>Oc1nccc2c1[nH]c1ccccc12</smiles>

26<smiles>C=Cc1ncc(OC)c2c1[nH]c1ccccc12</smiles>

19<smiles>COc1cccc2c1[nH]c1cncc(OC)c12</smiles>

23

$\mathrm{HO}$<smiles>Oc1nccc2c1[nH]c1ccc(I)cc12</smiles>

27<smiles>C=Cc1ncc(OC)c2c3ccccc3n(OC)c12</smiles>

20<smiles>O=C(O)C(O)c1nccc2c1[nH]c1ccccc12</smiles>

24<smiles>COc1cnc(C)c2[nH]c3ccccc3c12</smiles>

28

Figure 2. Structure of $\beta$-carboline alkaloids (2). Chemical formula of compounds 17-28 and the corresponding names: 17) 1-(2-ethylamino)-ethyl-4-methox yl-8-hydroxy- $\beta$-carboline, 18$)$ 1-ethyl-4-methoxyl- $\beta$-carboline, 19$) 1$-vinyl-4-methoxyl- $\beta$-carboline, 20$) 1$-vinyl-4,9-dimethoxy- $\beta$-carboline, 21$)$ 1-(1-carbony 1-2-methoxybutyly)-4,8-dimethoxy- $\beta$-carboline, 22 ) 1-carboxypropyl- $\beta$-carboline, 23 ) 4,8-dimethoxy- $\beta$-carboline, 24$) 1$-(2-hydroxy)-carboxypropyl- $\beta$-carbo line, 25) 1-(1,2-hydroxy)-carboxypropyl- $\beta$-carboline, 26) 1-hydroxy- $\beta$-carboline, 27) 1,6-dihydroxy- $\beta$-carboline and 28$) 1$-methyl-4-methoxyl- $\beta$-carboline. 
<smiles>COc1cnc(C=O)c2[nH]c3ccccc3c12</smiles>

29<smiles>COC(=O)c1ncc(OC)c2c1[nH]c1c(O)cccc12</smiles>

33<smiles>O=C1NC(=O)c2[nH]c3ccccc3c2C1=O</smiles>

37<smiles>COc1cnc(CCO)c2[nH]c3ccccc3c12</smiles>

30<smiles>COc1cnc(C(O)CO)c2[nH]c3ccccc3c12</smiles>

34<smiles>COc1cccc2c3c([nH]c12)C(=O)C(=O)NC3=O</smiles>

38<smiles>COc1cccc2c1[nH]c1c(C(C)O)ncc(OC)c12</smiles>

31<smiles>CCC(O)C(=O)c1ncc(OC)c2c1[nH]c1ccccc12</smiles>

35<smiles>COc1cccc2c1[nH]c1c(CO)ncc(OC)c12</smiles>

32<smiles>COc1cccc2c1[nH]c1c(C(O)CO)ncc(OC)c12</smiles>

36

Figure 3. Structure of $\beta$-carboline alkaloids (3). Chemical formula of compounds $29-38$ and the corresponding names: 29 ) 1-formyl-4-methoxyl- $\beta$-carboline, 30) 1-(2-dihydroxy)-ethyl-4-methoxyl- $\beta$-carboline, 31 ) 1-(1-hydroxy)-ethyl-4,8-dimethoxy- $\beta$-carboline, 32) 1-(2-hydroxy)-ethyl-4,8-dimethoxy- $\beta$-carboline, 33) 1-methoxyformacyl-4-methoxyl-8-hydroxy- $\beta$-carboline, 34) 1-(1,2-dihydroxy)-ethyl-4-methoxyl- $\beta$-carboline, 35) 1-(2-ethoxyethanol)-4-methoxyl- $\beta$-c arboline, 36) 1-(1,2-dihydroxy)-ethyl-4,8-dimethoxy- $\beta$-carboline, 37) 1,2,3,4-tetrahydro-1,3,4,-trioxo- $\beta$-carboline and 38) 8-methoxyl-1,2,3,4-tetrahydro-1, 3,4, -trioxo- $\beta$-carboline.<smiles>O=c1ccc2nccc3c4ccccc4n1c23</smiles>

39<smiles>O=c1ccc2nccc3c4cccc(O)c4n1c23</smiles>

43<smiles>CN1C(=O)CC2c3ccccc3-n3c2c1ccc3=O</smiles>

47<smiles>COc1c(OC)c2nccc3c4ccccc4n(c1=O)c23</smiles>

40<smiles>COc1cc2nccc3c4ccccc4n(c1=O)c23</smiles>

44<smiles></smiles>

48<smiles>COc1cc(=O)n2c3ccccc3c3ccnc1c32</smiles>

41<smiles>COc1c(O)c2nccc3c4cc(O)ccc4n(c1=O)c23</smiles>

45<smiles>COc1c2n(C)ccc3c-2n(c(=O)c1=O)c1ccccc31</smiles>

49<smiles>O=c1ccc2nccc3c4c(O)cccc4n1c23</smiles>

42<smiles>COc1c(O)c2nccc3c4ccccc4n(c1=O)c23</smiles>

46<smiles>Cn1ccc2c3n(c(=O)c(=O)c(O)c1-3)c1ccccc21</smiles>

50

Figure 4. Structure of canthinone alkaloids. Chemical formula of compounds 39-50 and the corresponding names: 39) canthin-6-one, 40) 4,5-dimethyl-canthin-6-one, 41) 4-methoxy-5-hydroxy-canthin-6-one, 42) 11-hydroxy-canthin-6-one, 43) 8-hydroxy-canthin-6-one, 44) 5-methoxy-canthin-6-one, 45) 4,10-dyhydroxy-5-methoxy-canthin-6-one, 46) 4-hydroxy-5-methoxy-canthin-6-one 47) 3-methyl-canthin-2,6-dione, 48) 3-methyl-canthin-5,6-dione, 49) 3-methyl-4-methoxyl-canthine-5,6-dione and 50) 3-methyl-4-hydroxy-canthine-5,6-dione. 
Table I. $\beta$-carboline alkaloids of Picrasma quassioides (D. Don) Benn.

\begin{tabular}{|c|c|c|}
\hline No. & Name & Basic structure (Fig. S1) \\
\hline 1 & 1-hydroxymethyl- $\beta$-carboline & (1) \\
\hline 2 & 1 -formyl- $\beta$-carboline & $(1)$ \\
\hline 3 & 1-methoxyformacyl- $\beta$-carboline & (1) \\
\hline 4 & 1-ethoxyformyl- $\beta$-carboline & (1) \\
\hline 5 & 1-vinyl-4,8-dimethoxy- $\beta$-carboline & (1) \\
\hline 6 & 1-formyl-4-methoxy- $\beta$-carboline & (1) \\
\hline 7 & 1-methoxypropionyl- $\beta$-carboline & $(1)$ \\
\hline 8 & 1-formyl-4-hydroxy- $\beta$-carboline & (1) \\
\hline 9 & 1-methoxyformacyl-4-hydroxy- $\beta$-carboline & (1) \\
\hline 10 & 1-methoxyl- $\beta$-carboline & $(1)$ \\
\hline 11 & $\beta$-carboline-1-methanoic acid & (1) \\
\hline 12 & 1-ethanoyl- $\beta$-carboline & (1) \\
\hline 13 & 1-ethyl-4,8-dimethoxy- $\beta$-carboline & $(1)$ \\
\hline 14 & 1-(2-methoxyl)-ethyl-4,8-dimethoxyl- $\beta$-carboline & $(1)$ \\
\hline 15 & 1-ethyl-4-methoxyl-8-hydroxy- $\beta$-carboline & $(1)$ \\
\hline 16 & 1-vinyl-4-methoxyl-8-hydroxy- $\beta$-carboline & $(1)$ \\
\hline 17 & 1-(2-ethylamino)-ethyl-4-methoxyl-8-hydroxy- $\beta$-carboline & $(1)$ \\
\hline 18 & 1-ethyl-4-methoxyl- $\beta$-carboline & (1) \\
\hline 19 & 1-vinyl-4-methoxyl- $\beta$-carboline & (1) \\
\hline 20 & 1-vinyl-4,9-dimethoxy- $\beta$-carboline & $(1)$ \\
\hline 21 & 1-(1-carbonyl-2-methoxybutyly)-4,8-dimethoxy- $\beta$-carboline & (1) \\
\hline 22 & 1-carboxypropyl- $\beta$-carboline & $(1)$ \\
\hline 23 & 4,8-dimethoxy- $\beta$-carboline & $(1)$ \\
\hline 24 & 1-(2-hydroxy)-carboxypropyl- $\beta$-carboline & (1) \\
\hline 25 & 1-(1,2-hydroxy)-carboxypropyl- $\beta$-carboline & $(1)$ \\
\hline 26 & 1-hydroxy- $\beta$-carboline & $(1)$ \\
\hline 27 & 1,6 -dihydroxy- $\beta$-carboline & (1) \\
\hline 28 & 1-methyl-4-methoxyl- $\beta$-carboline & $(1)$ \\
\hline 29 & 1-formyl-4-methoxyl- $\beta$-carboline & (1) \\
\hline 30 & 1-(2-dihydroxy)-ethyl-4-methoxyl- $\beta$-carboline & (1) \\
\hline 31 & 1-(1-hydroxy)-ethyl-4,8-dimethoxy- $\beta$-carboline & (1) \\
\hline 32 & 1-(2-hydroxy)-ethyl-4,8-dimethoxy- $\beta$-carboline & (1) \\
\hline 33 & 1-methoxyformacyl-4-methoxyl-8-hydroxy- $\beta$-carboline & (1) \\
\hline 34 & 1-(1,2-dihydroxy)-ethyl-4-methoxyl- $\beta$-carboline & $(1)$ \\
\hline 35 & 1-(2-ethoxyethanol)-4-methoxyl- $\beta$-carboline & (1) \\
\hline 36 & 1-(1,2-dihydroxy)-ethyl-4,8-dimethoxy- $\beta$-carboline & $(1)$ \\
\hline 37 & 1,2,3,4-tetrahydro-1,3,4-trioxo- $\beta$-carboline & $(2)$ \\
\hline 38 & 8-methoxyl-1,2,3,4-tetrahydro-1,3,4-trioxo- $\beta$-carboline & $(2)$ \\
\hline
\end{tabular}

$P$. quassioides extracts also inhibit TNF- $\alpha$ and IL- 8 release in the colon of a trinitrobenzene sulfonic acid-induced colitis mouse model (28).

Anti-inflammatory effects of $\beta$-carboline alkaloids. 6-Methoxy-3-vinyl- $\beta$-carboline and 6,12-dimethoxy-3vinyl- $\beta$-carboline were demonstrated to have inhibitory effects on NO, TNF- $\alpha$ and IL-6 secretion in LPS-induced RAW264.7 cells (27). 3-Methylcanthin-5,6-dione inhibited LPS-stimulated NO production in RAW264.7 cells and had antioxidant activity (29). Benzalharman, kumujian, 1-ethyl1,2,3,4-tetrahydro- $\beta$-carboline-3-carboxylic acid and 1-acet ophenone-1,2,3,4-tetrahydro- $\beta$-carboline-3-carboxylic acid inhibited excessive NO production and downregulated iNOS expression in RAW264.7 cells activated by LPS but had no evident inhibitory effect on COX-2 protein expression (30).

Anti-inflammatory effects of carthinone alkaloids. 4-Methoxy-5-hydroxycanthin-6-one significantly inhibited LPS-induced NO and TNF- $\alpha$ release and downregulated iNOS expression to achieve anti-inflammatory activity in RAW264.7 cells (31). Cathin-6-one and 9-methoxy-cathin-6-one inhibited NO production and downregulated iNOS and COX-2 expression in LPS-activated RAW264.7 cells. Furthermore, 
Table II. Canthinone alkloids of Picrasma quassioides (D. Don) Benn.

\begin{tabular}{lll}
\hline No. & \multicolumn{1}{c}{ Name } & Basic structure \\
\hline 39 & Canthin-6-one & $(3)$ \\
40 & 4,5-dimethyl-canthin-6-one & $(3)$ \\
41 & 4-methoxy-5-hydroxy-canthin-6-one & $(3)$ \\
42 & 11-hydroxy-canthin-6-one & $(3)$ \\
43 & 8-hydroxy-canthin-6-one & $(3)$ \\
44 & 5-methoxy-canthin-6-one & $(3)$ \\
45 & 4,10-dyhydroxy-5-methoxy-canthin-6-one \\
46 & 4-hydroxy-5-methoxy-canthin-6-one & $(3)$ \\
47 & 3-methyl-canthin-2,6-dione & $(4)$ \\
48 & 3-methyl-canthin-5,6-dione & $(5)$ \\
50 & 3-methyl-4-methoxyl-canthine-5,6-dione & $(5)$ \\
\hline
\end{tabular}

Table III. Bis- $\beta$-carboline alkaloids of Picrasma quassioides (D. Don) Benn.

\begin{tabular}{llc}
\hline No. & Name & Basic structure \\
\hline 51 & Picrasidine A & $(6)$ \\
52 & Picrasidine C & $(7)$ \\
53 & Picrasidine F & $(9)$ \\
54 & Picrasidine G & $(9)$ \\
55 & Picrasidine H & $(6)$ \\
56 & Picrasidine M & $(8)$ \\
57 & Picrasidine N & $(8)$ \\
58 & Picrasidine U & $(8)$ \\
59 & Picrasidine S & $(9)$ \\
60 & Picrasidine R & $(7)$ \\
\hline
\end{tabular}

this molecule downregulated prostaglandin E2 expression in a dose-dependent manner (30). In vivo, the antihypertensive effect of 1:4-methoxy-5-hyroxycanthin-6-one is probably associated with reduced superoxide dismutase activity and increased eNOS expression, which preserves endothelial function and directly relaxes the aorta in spontaneously hypertensive rats (32). 9-methoxy-cathin-6-one may also be used to treat dextran sulfate sodium-induced ulcerative colitis (33) and reduce Freund's adjuvant-induced chronic arthritis, while intragastric 4-methoxy-5-hydroxycanthin-6-one administration for 28 days ameliorated arthritis symptoms in rats (31). These studies indicated that 4-methoxy-5-hydroxycanthin-6-one has good anti-inflammatory activity. Similarly, canthin-6-one or 4-methoxycanthin-6-one used alone or in conjunction demonstrated potent antiulcerogenic effects when evaluated in gastric lesion-induced mice (34). Meanwhile, in rat and mouse models of gastric ulcers, cathin-6-one reduced the myeloperoxidase and malonaldehyde production in the stomach and inhibited IL- 8 and TNF- $\alpha$ release into the serum, which alleviated gastric ulceration (35). Picrasidine L promoted insulin signaling pathway activation and effectively inhibited protein tyrosine phosphatase (PTP) 1B (36), a non-transmembrane PTP that may be produced in large quantities in insulin-targeted tissues (37).

Anti-inflammatory effects of bis- $\beta$-carboline alkaloids. Quassidine A, a bis- $\beta$-carboline alkaloid, possesses a novel cyclobutane moiety; however, this molecule exhibited weak anti-inflammatory activity (38). By contrast, quassidine E and quassidine $\mathrm{G}$ inhibited NO, TNF- $\alpha$ and IL-6 release. In anti-inflammatory activity experiments in vitro, quassidine $\mathrm{F}$ isolated from $P$. quassioides had inhibitory effects on $\mathrm{NO}$ and IL-6 production, but not on TNF- $\alpha$ release (39). Furthermore, certain studies suggested that the anti-inflammatory mechanism of quassidine $\mathrm{F}$ is mediated by inhibiting the iNOS signaling pathway (27). Picrasidine $\mathrm{C}$ and picrasidine $\mathrm{N}$ are peroxisome proliferator-activated receptor (PPAR) $\alpha$ (2) and PPAR $\beta / \delta$ agonists (40). Indeed, picrasidine $N$ selectively activates the PPAR $\beta / \delta$ target gene ANGPTL4 (41) to regulate various physiological functions such as facilitating skin wound healing (42) and reducing atherosclerosis development (43). Picrasmalignan A (quassinoids drug) reduced NO, TNF- $\alpha$ and IL-6 production in LPS-induced macrophages and upregulated iNOS and COX-2 expression in vitro (44).

\section{Anticancer role of Picrasma quassioides (D. Don) Benn}

Cancer is caused by the continuous proliferation and abnormal differentiation of cells. Worldwide, cancer is the second major cause of death in humans. Of note, cancer is a complex, multi-factorial disease, which makes treatment difficult and poses several challenges for survival $(45,46)$. In recent years, cancer awareness has markedly improved, and treatments have also been developed. In spite of efforts regarding the early detection and timely treatment of cancer, cancer-associated mortality is at an all-time high (47). The currently available clinical treatments for cancer mainly include surgical treatment, radiotherapy and chemotherapy (48). Early cancer detection generally leads to surgical treatment, whereas chemotherapy is mainly used for advanced cancer. Commonly 


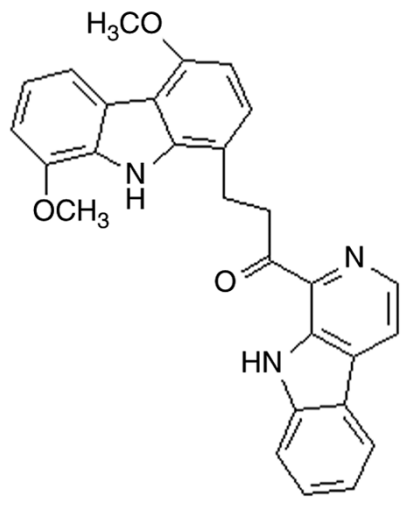

51

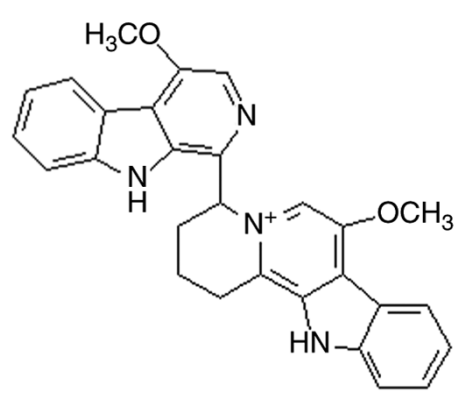

54

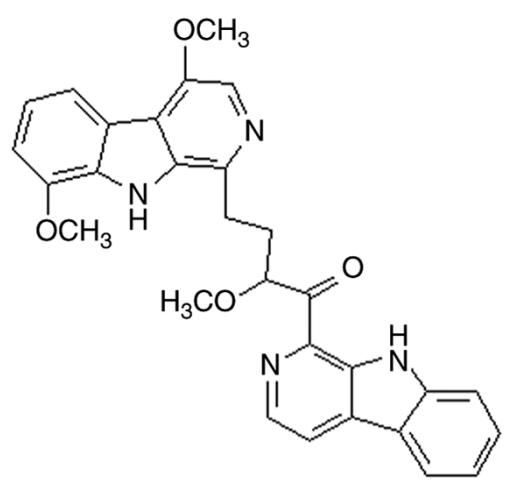

52

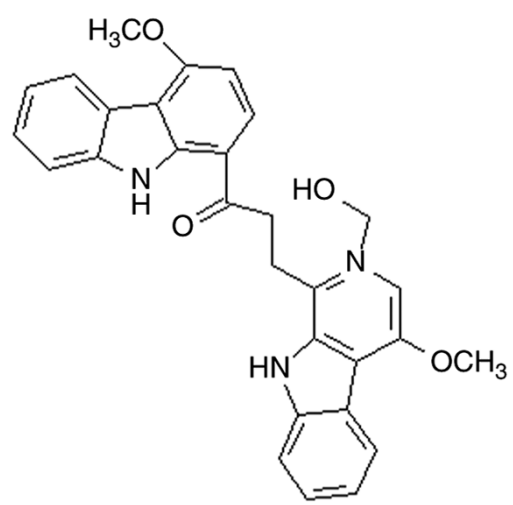

55<smiles></smiles>

53<smiles>COc1cccc2c1[nH]c1c(CCN3C=Cc4cc(=O)c(=O)n5c(c4c4ccccc45)C=C3)ncc(OC)c12</smiles>

56

Figure 5. Structure of bis- $\beta$-carboline alkaloids (1). Chemical formula of compounds 51-56 and the corresponding names: 51) Picrasidine A, 52) picrasidine C, 53) picrasidine $F, 54$ ) picrasidine $G, 55$ ) picrasidine $H$ and 56) picrasidine $M$.<smiles>COC1=Cc2c3c(c4n2C(=O)C(=O)C=C4N(CCc2ncc(OC)c4c2[nH]c2ccccc24)C=C3)C=C1</smiles>

57<smiles>COc1cccc2c1[nH]c1c(CCCC(=O)c3ncc(OC)c4c3[nH]c3c(OC)cccc34)ncc(OC)c12</smiles>

60

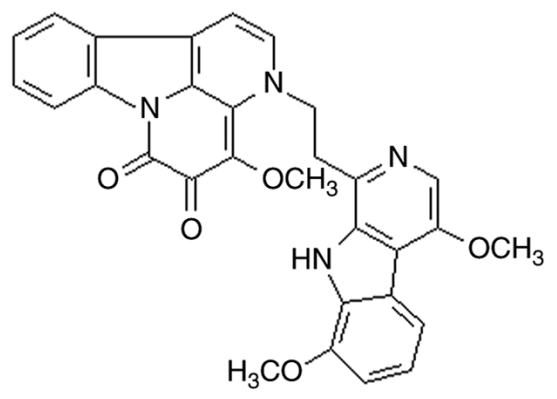

58

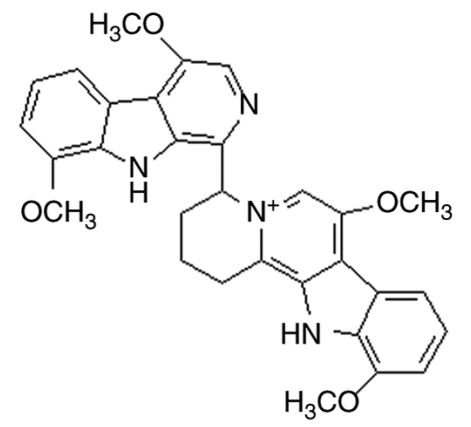

59

Figure 6. Structure of bis- $\beta$-carboline alkaloids (2). Chemical formula of compounds 57-60 and the corresponding names: 57) Picrasidine N, 58) picrasidine U, 59) picrasidine $S$ and 60) picrasidine $R$. 


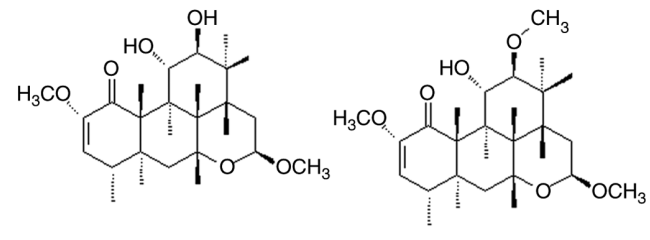

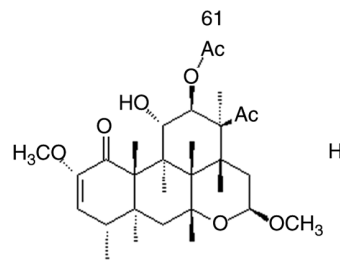

65<smiles>COC1=CC(OC)C2C3C(OC)C(OC)=CC(C)C3(C)CC3(C)OC(OC)CCC23C1=O</smiles>

66

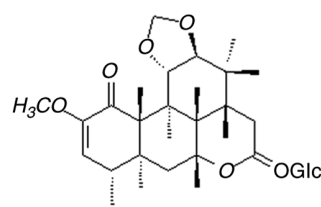

69

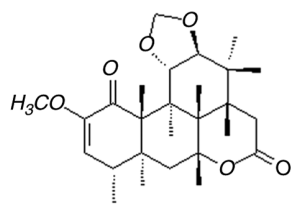

73

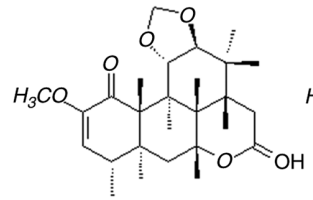

70

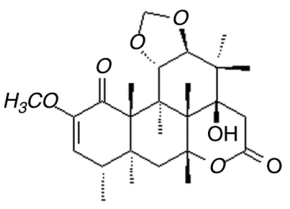

74

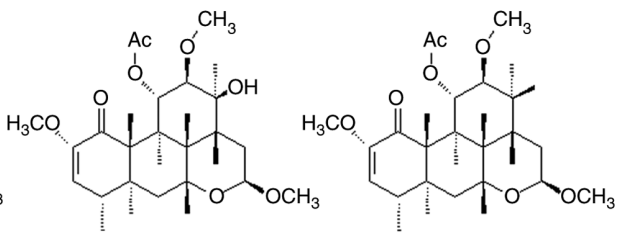

63

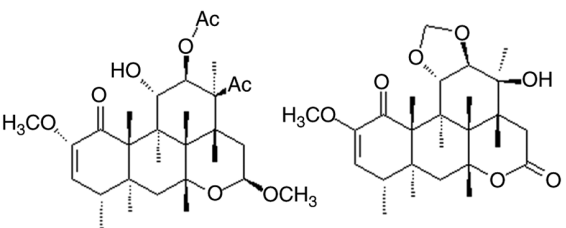

67

68

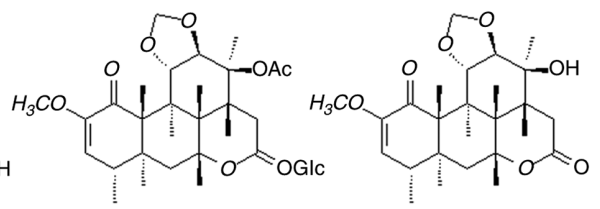

71

72

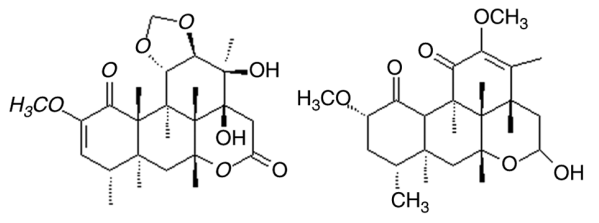

75

76

Figure 7. Structure of quassinoids (1). Chemical formula of compounds 61-76 and the corresponding names: 61) nigakilacetone A, 62) nigakilacetone B, 63) nigakilacetone $\mathrm{C}$, 64) nigakilacetone $\mathrm{E}, 65$ ) nigakilacetone $\mathrm{F}, 66$ ) nigakihihemiacetal $\mathrm{D}, 67$ ) kumulactone, 68) nigakilacetone $\mathrm{L}, 69)$ picrasinoside $\mathrm{C}$, 70) picrasion $\mathrm{B}, 71$ ) nigakilactone $\mathrm{H}, 72$ ) picrasin $\mathrm{D}, 73$ ) picrasin $\mathrm{C}, 74)$ picrasin $\mathrm{D}, 75$ ) picrasin $\mathrm{E}$ and 76 ) nigakihihemiacetal $\mathrm{B}$.

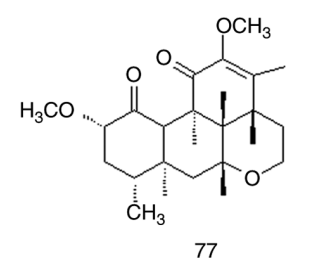

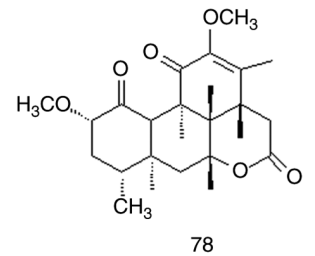

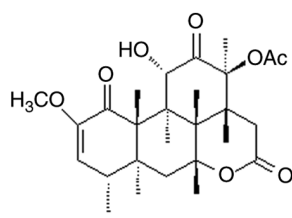

79

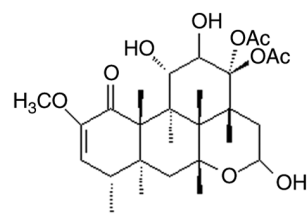

80

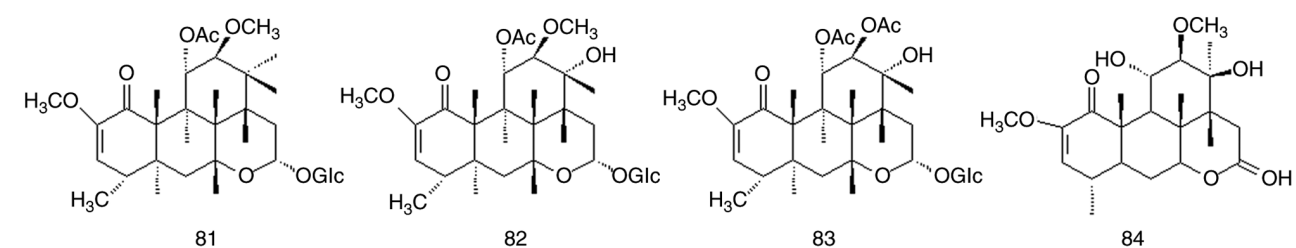

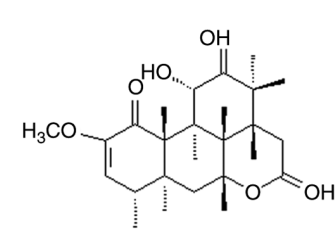

82

83

84

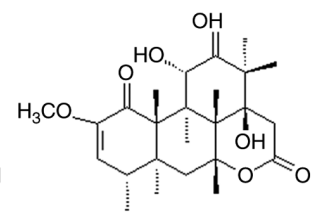

86

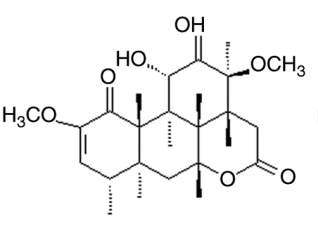

87

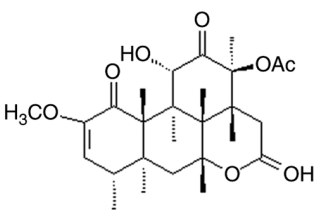

88

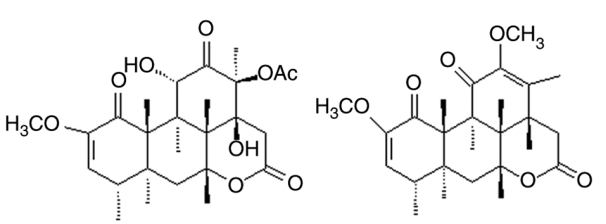

90

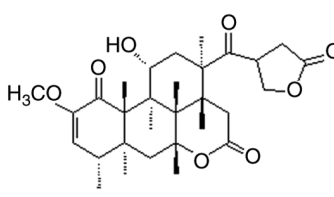

91

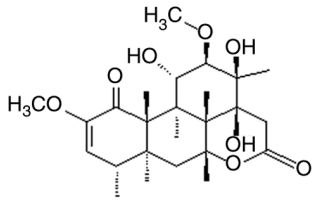

92

Figure 8. Structure of quassinoids (2). Chemical formula of compounds 77-92 and the corresponding names: 77) picrasinoside B, 78) quassin, 79) Picraqualide D, 80) picraqualide E, 81) Picrasinoside D, 82) picrasinoside E, 83) picrasinoside G, 84) nigakihihemiacetal A, 85) nigakihihemiacetal C, 86) nigakilactone M, 87) nigakilactone $N, 88$ ) picraqualide $A, 89$ ) picraqualide $C, 90$ ) nigakilactone $D, 91$ ) nigakilactone $G$ and 92 ) nigakilactone $H$. 
Table IV. $\beta$-carboline alkloids of Picrasma quassioides (D. Don) Benn.

\begin{tabular}{|c|c|c|}
\hline No. & Name & Basic structure \\
\hline 61 & Nigakilacetone A & $(10)$ \\
\hline 62 & Nigakilacetone B & $(10)$ \\
\hline 63 & Nigakilacetone C & $(10)$ \\
\hline 64 & Nigakilacetone E & $(10)$ \\
\hline 65 & Nigakilacetone F & $(10)$ \\
\hline 66 & Nigakihihemiacetal D & (12) \\
\hline 67 & Kumulactone & $(10)$ \\
\hline 68 & Nigakilacetone L & $(10)$ \\
\hline 69 & Picrasinoside C & (12) \\
\hline 70 & Picrasionol B & (12) \\
\hline 71 & Nigakilacetone $\mathrm{H}$ & (10) \\
\hline 72 & Picrasinol D & $(12)$ \\
\hline 73 & Picrasin C & $(10)$ \\
\hline 74 & Picrasin D & (10) \\
\hline 75 & Picrasin E & (10) \\
\hline 76 & Nigakihihemiacetal B & (12) \\
\hline 77 & Picrasinoside B & (12) \\
\hline 78 & Quassin & (12) \\
\hline 79 & Picraqualide D & $(10)$ \\
\hline 80 & Picraqualide E & (12) \\
\hline 81 & Picrasinoside D & $(12)$ \\
\hline 82 & Picrasinoside E & (12) \\
\hline 83 & Picrasinoside $\mathrm{G}$ & $(12)$ \\
\hline 84 & Nigakihihemiacetal A & $(12)$ \\
\hline 85 & Nigakihihemiacetal C & (12) \\
\hline 86 & Nigakilacetone M & (10) \\
\hline 87 & Nigakilacetone $\mathrm{N}$ & $(10)$ \\
\hline 88 & Picraqualide A & $(12)$ \\
\hline 89 & Picraqualide $\mathrm{C}$ & $(10)$ \\
\hline 90 & Nigakilacetone D & $(10)$ \\
\hline 91 & Nigakilacetone G & $(10)$ \\
\hline 92 & Nigakilacetone $\mathrm{H}$ & $(10)$ \\
\hline 93 & Picrasin G & (10) \\
\hline 94 & Nigakilacetone J & (10) \\
\hline 95 & Nigakilacetone K & $(10)$ \\
\hline 96 & Nigakihihemiacetal E & $(12)$ \\
\hline 97 & Nigakihihemiacetal F & $(12)$ \\
\hline 98 & Picrasinoside A & $(12)$ \\
\hline 99 & Picrasinol A & $(12)$ \\
\hline 100 & Nigakilacetone $\mathrm{O}$ & $(10)$ \\
\hline 101 & Picrasinol C & (12) \\
\hline 102 & Picrasin A & (11) \\
\hline 103 & Picrasin B & (10) \\
\hline 104 & Picraqualide B & (10) \\
\hline 105 & Picrasin F & (10) \\
\hline
\end{tabular}

used chemotherapy drugs include 5-fluorouracil, cisplatin, paclitaxel and doxorubicin (49). However, the toxic side effects of chemotherapy drugs affect patient health (50). Natural
Chinese herbal medicine has become a hot topic in anticancer research in recent years due to low toxicity and reduced side effects of various herbal formulations (51).

Several studies indicated that the crude extracts or compounds derived from Chinese herbal medicines effectively inhibited the proliferation of liver, gastric, lung, breast and colon cancer cells and induced cancer cell apoptosis (50-54). The pathways that induce cell death include the intrinsic pathway, extrinsic pathway and the endoplasmic reticulum (ER) stress pathway (47). The intrinsic pathway is also called the mitochondrial pathway. During apoptosis, various mitochondrial components integrate cell death signals and mediate the progression of apoptosis (55). The extrinsic pathway is activated by cell surface death receptors, such as Fas and TNF receptor (56). ER stress causes caspase-12 activation and induces apoptosis (57). ER stress may also promote DNA damage and autophagy-induced cell death (58). It is possible that chemotherapy drugs directly act on genes or proteins to stimulate the activation of downstream signaling pathways, involving B-cell lymphoma-2, MAPK, phosphatidylinositol 3-kinase/protein kinase $B$ and recombinant glycogen synthase kinase 3 beta, to induce cell death (59-62).

$P$. quassioides extracts may induce cervical cancer cell apoptosis by upregulating the expression of the pro-apoptotic proteins Bad and t-Bad (63). In addition, these extracts may activate the reactive oxygen species (ROS)-mitochondria axis to cause death of SiHa human cervical cancer cells (64). Ethanolic extracts of $P$. quassioides also induced H-Ras ${ }^{\mathrm{G} 12 \mathrm{~V}}$ liver cancer cell apoptosis (65), whereas the n-butanol extract induced HT-29 colon and NCI-N87 gastric cancer cell apoptosis. Importantly, these extracts exhibited no cytotoxicity to 293T normal human cells (66).

Anticancer effects of $\beta$-carboline alkaloids. 4-Methoxy-1-vinyl- $\beta$-carboline and 1-methoxy- $\beta$-carboline are cytotoxic to A2780 and SKOV3 human ovarian cancer cells and exhibited excellent antitumor activity (67). $\beta$-carboline-1-carboxylic acid, isolated from the stem of $P$. quassioides, demonstrated moderate inhibitory activities against K562 leukemia cancer cells and SGC-7901 human gastric cancer cells (68) (Table VII).

Anticancer effects of carthinone alkaloids. In vitro, 9-methoxy-canthin-6-one and canthin-6-one isolated from $P$. quassioides demonstrated significant cytotoxic activity against A549 lung cancer and MCF-7 breast cancer cells (69). Furthermore, 4,5-dimethoxy-10-hydroxy-canthin-6-one, canthin-6-one alkaloids, 8-hydroxy-canthin-6-one, 4,5-dimethoxy-canthin-6-one and 5-hydroxy-4-methoxycanthin-6-one exhibited significant cytotoxic activity against CNE2 nasopharyngeal carcinoma cells. Thus, carthinone alkaloids may be used to effectively treat various cancer types (70).

Anticancer effects of bis- $\beta$-carboline alkaloids. A novel bimolecular compound (B-9-3), synthesized from two $\beta$-carboline alkaloids, promoted cell death by causing necrotic apoptosis and reducing proliferation of NCI-H460 human non-small-cell lung cancer cells, T47D breast cancer cells and HCT-116 colon cancer cells (71). Two novel bis- $\beta$-carboline alkaloids, quassidines I and J, had cytotoxicity in HeLa human cervical cancer 
<smiles>COC1=C(C)C2CC(=O)OC3CC4C(C)CC(O)C(=O)C4(C)C3C2=CC1=O</smiles>

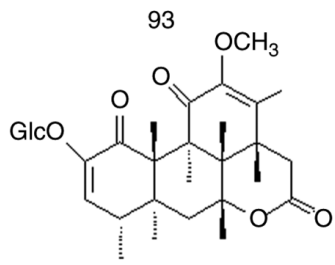

97

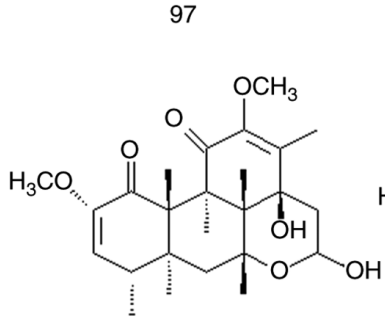

101

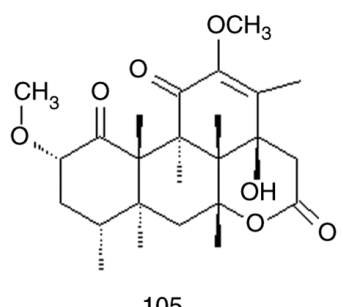

105

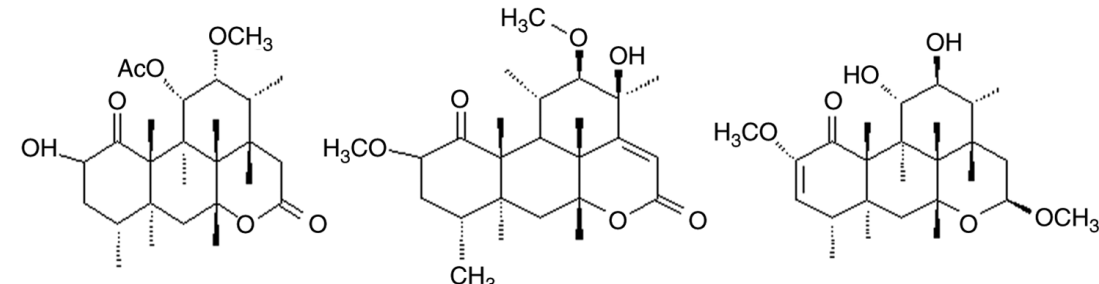

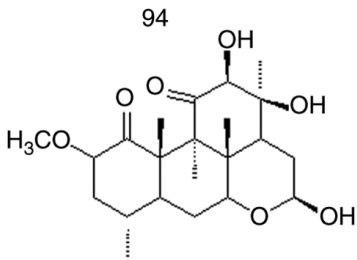

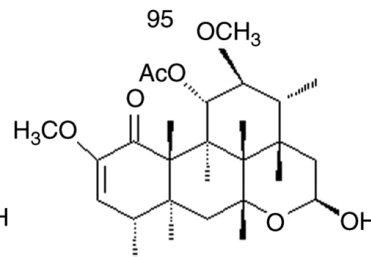<smiles>O=C(O)c1ccc2c(c1)OCO2</smiles><smiles>O</smiles>

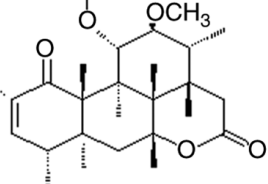

100

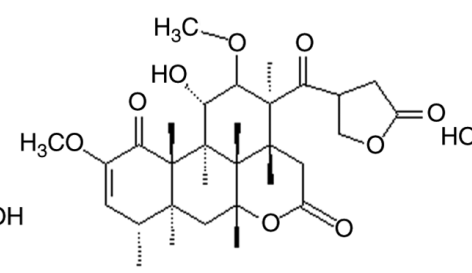

102
99

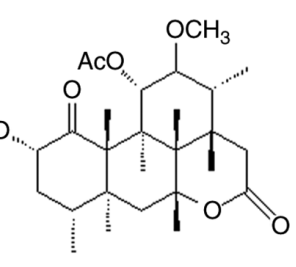

103

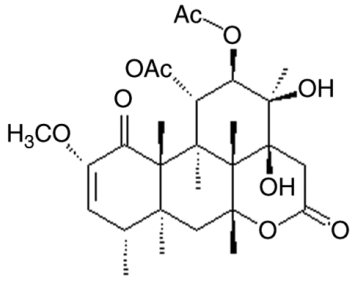

104

Figure 9. Structure of quassinoids (3). Chemical formula of compounds 93-105 and the corresponding names: 93) Picrasin G, 94) nigakilactone J, 95) nigakilactone $\mathrm{K}, 96$ ) nigakihihemiacetal $\mathrm{E}$, 97) nigakihihemiacetal $\mathrm{F}$, 98) picrasinoside $\mathrm{A}$, 99) picrasinoside $\mathrm{A}, 100$ ) nigakilactone $\mathrm{O}$, 101) picrasinol $\mathrm{C}$, 102) picrasin $\mathrm{A}$, 103) picrasin $\mathrm{B}, 104)$ picraqualide $\mathrm{B}$ and 105) picrasin $\mathrm{F}$.

cells, MKN-28 gastric cancer cells and mouse melanoma B-16 cancer cells (72). In MDA-MB 468 human breast cancer cells, picrasidine $\mathrm{G}$ treatment increased the expression of apoptosis markers and inhibited the EGFR/STAT3 signaling pathway (73).

Anticancer effects of triterpenoids. The novel tirucallane-type triterpenoid kumuquassin $\mathrm{C}$, isolated from the stem of $P$. quassioides, had excellent cytotoxic effects and blocked cell cycle progression in G1 phase in HepG2 liver cancer cells, thereby inducing cell apoptosis (74).

\section{Neuroinflammatory role of Picrasma quassioides (D. Don) Benn}

Neurological diseases cause physical damage to the nervous system, impairing human health and well-being. Such diseases include Alzheimer's disease (75). Through the isolation and extraction of plants and the ELISA test, it was determined that the drug resistance of certain bitter wood extracts was related to the deposition of neuroinhibitors and reduction of $A \beta 142$. Further exploration of the structure-activity relationship of alkaloids and molecular docking experiments suggested that certain active components of $P$. quassioides (D. Don) Benn extracts may have efficacy for treating neurodegenerative diseases. In addition, the $\beta$-carboline alkaloids of sorrel wood extracts as benzodiazepine antagonists are able to effectively control social anxiety, convulsions and other types of behavior in mouse models $(76,77)$. As major diseases in humans, neurological diseases are accompanied by changes in the corresponding enzymes monoamine oxidase (MAO)-A and MAO-B (78,79); furthermore, the levels of ROS increased in cells and damage to mitochondria occurred (80-82).

$\beta$-carboline alkaloids and neuroinflammation. 7-(4,4,4-Triflu orobutoxy)-1-methyl- $\beta$-carboline and 7-(cyclohexylmethoxy)1 -methyl- $\beta$-carboline exert inhibitory effects on MAO-A and MAO-B. These enzymes are important targets for intervention and treatment of diseases, such as clinical depression, anxiety and Parkinson's disease (83).

Canthinone alkaloids and neuroinflammation. It has been observed that picrasidine $\mathrm{O}$ improves learning and memory performance while reducing neurotransmitter-induced nerve 
Table V. Triterpenoids of Picrasma quassioides (D. Don) Benn.

No.

Name

Basic structure

106

107

108

109

110

111

112

113
(24Z)-3 $\alpha$-oxahomo-27-hydroxy-7,24-triucalladien-3-one

(24Z)-27-hydroxy-3-oxo-7,24-triucalladien-21-al

(24Z)-27-hydroxy-3-oxo-7,24-triucalladien-3-one

(24Z)-27-hydroxy-3-oxo-7,24-triucalladien-21-diol

(24Z)-7,24-triucalladien-ene-3 $\beta, 27$-diol

(24Z)-3ß,27-dihydroxy-7,24-triucalladien-ene-21-al

Hiapidol A

Lanosta-7,24-dien-3-one<smiles>C/C(=C/CCC(C)[C@H]1CC[C@]2(C)C3=CC[C@H]4C(C)(C)C(=O)CC[C@]4(C)[C@@H]3CC[C@]12C)CO</smiles>

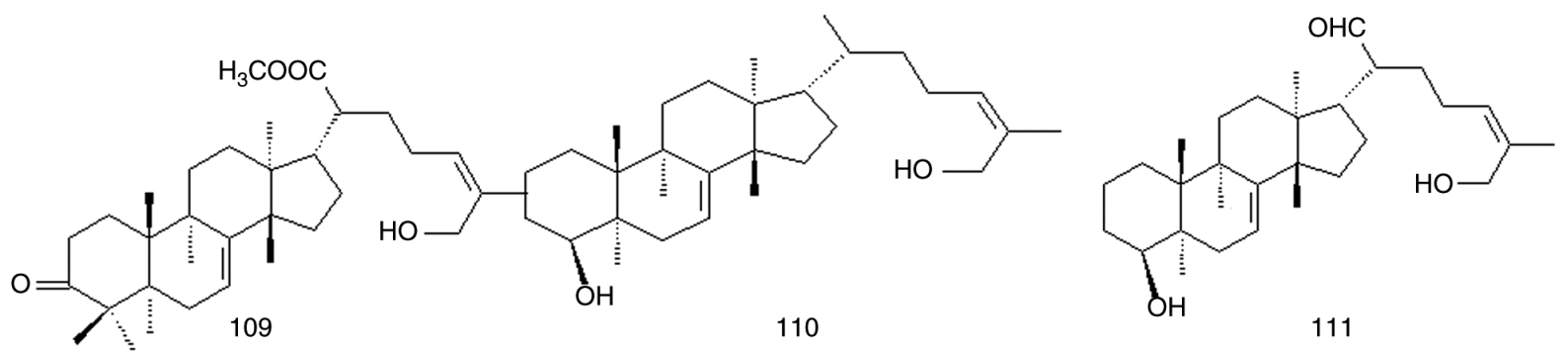

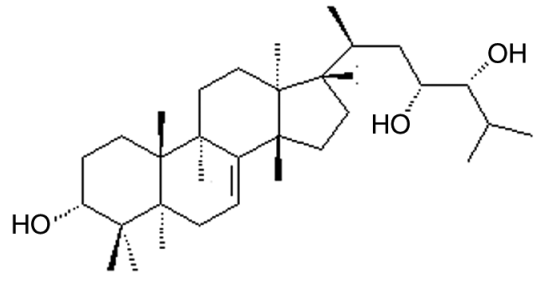

112<smiles>CC(=O)C(CCC=C(C)C)[C@H]1CC[C@H]2C3=CC[C@H]4[C@@H](C)C(=O)CC[C@]4(C)[C@H]3CC[C@@H]12</smiles>

Figure 10. Structure of triterpenoids. Chemical formula of compounds 106-113 and the corresponding names: 106) (24Z)-3 $\alpha$-oxahomo-27-hydroxy-7,24-t riucalladien-3-one, 107) (24Z)-27-hydroxy-3-oxo-7,24-triucalladien-21-al, 108) (24Z)-27-hydroxy-3-oxo-7,24-triucalladien-3-one, 109) (24Z)-27-hydroxy-3

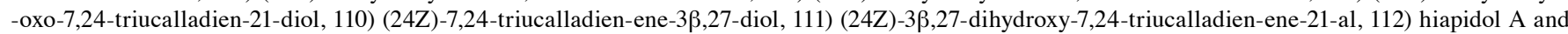
113) lanosta-7,24-dien-3-one.

cell death and injury. In addition a, picrasidine $\mathrm{O}$ has no side effects on the heart rate and blood pressure (84). Furthermore, two classical canthin alkaloids, canthin-6-one and 5-methoxycanthin-6-one, have good antioxidant capacity and may be used to prevent degenerative diseases and aging (85).

Quassinoids and neuroinflammation. In vitro experiments with quassin, picrasin $\mathrm{B}$ and nigakilactone $\mathrm{F}$ (86) demonstrated excellent neuroprotective effects against $\mathrm{H}_{2} \mathrm{O}_{2}$-induced oxidative stress in SH-SY5Y human neuroblastoma cells. Of note, these compounds had potent activity that was equal to the effects of trolox, but none of them had any cytotoxic activity towards HeLa or A549 cells. These results suggested that quassinoid compounds may have specific protective effects on neurons (87).

\section{Clinical applications and developmental prospects of Picrasma quassioides (D. Don) Benn}

Since the 1970s, numerous researchers have investigated $P$. quassioides, including its chemical components and pharmacological effects. However, as an Asian traditional medicine, P. quassioides exerts its effects via individual chemical components and through synergistic effects of several compounds. 
Table VI. Anti-inflammatory effects of components of Picrasma quassioides (D. Don) Benn.

A, $\beta$-carboline alkaloids

\begin{tabular}{|c|c|c|}
\hline Compound & Mechanism & (Refs.) \\
\hline 6-methoxy-3-vinyl- $\beta$-carboline & Inhibit the secretion of NO, TNF- $\alpha$ and IL-6 & $(27)$ \\
\hline 6,12-dimethoxy-3-vinyl- $\beta$-carboline & Inhibit the secretion of NO, TNF- $\alpha$ and IL- 6 & $(27)$ \\
\hline 3-methylcanthin-5,6-dione & Inhibit the production of $\mathrm{NO}$ & $(29)$ \\
\hline Benzalharman & Inhibit the production of $\mathrm{NO}$ & (30) \\
\hline Kumujian & Inhibit the production of $\mathrm{NO}$ & $(30)$ \\
\hline 1-ethyl-1,2,3,4-tetrahydro- $\beta$-carboline-3-carboxylic acid & Inhibit the production of $\mathrm{NO}$ & $(30)$ \\
\hline 1 -acetophenone-1,2,3,4-tetrahydro- $\beta$-carboline-3-carboxylic acid & Inhibit the production of $\mathrm{NO}$ & $(30)$ \\
\hline
\end{tabular}

B, Carthinone alkaloids

\begin{tabular}{|c|c|c|}
\hline Compound & Mechanism & (Refs.) \\
\hline 4-methoxy-5-hydroxycanthin-6-one & $\begin{array}{l}\text { Inhibit NO and TNF- } \alpha \text { release and } \\
\text { down-regulation iNOS expression }\end{array}$ & $(31)$ \\
\hline Cathin-6-one & $\begin{array}{l}\text { Inhibit NO production and down-regulation } \\
\text { iNOS, COX-2 and PGE } 2 \text { expression. } \\
\text { Reduce MPO and MDA production and } \\
\text { inhibit IL- } 8 \text { and TNF- } \alpha \text { release }\end{array}$ & $(30,35)$ \\
\hline 9-methoxy-cathin-6-one & $\begin{array}{l}\text { Inhibit NO production and down-regulation } \\
\text { iNOS, COX-2 and PGE } 2 \text { expression }\end{array}$ & $(30)$ \\
\hline 1:4-methoxy-5-hyroxycanthin-6-one & $\begin{array}{l}\text { Reduce SOD activity and increase eNOS } \\
\text { expression }\end{array}$ & $(32)$ \\
\hline $\begin{array}{l}\text { Picrasidine L } \\
\text { inhibit PTP-1B }\end{array}$ & Promote insulin signaling pathway activation; & $(36)$ \\
\hline
\end{tabular}

C, Bis- $\beta$-carboline alkaloids

\begin{tabular}{|c|c|c|}
\hline Compound & Mechanism & (Refs.) \\
\hline Quassidine E & Inhibit NO, TNF- $\alpha$ and IL-6 release & (39) \\
\hline Quassidine G & Inhibit NO, TNF- $\alpha$ and IL-6 release & (39) \\
\hline Quassidine F & $\begin{array}{l}\text { Only inhibit the secretion of NO and IL- } 6 \text { and } \\
\text { the iNOS signaling pathway }\end{array}$ & $(39,27)$ \\
\hline Picrasidine $\mathrm{C}$ & $\operatorname{PPAR} \alpha$ and $\mathrm{PPAR} \beta / \delta$ agonists & $(40)$ \\
\hline Picrasidine $\mathrm{N}$ & $\begin{array}{l}\text { PPAR } \alpha, \operatorname{PPAR} \beta / \delta \text { agonist and selectively } \\
\text { activate the PPAR } \beta / \delta \text { target gene ANGPTL } 4\end{array}$ & $(40,41)$ \\
\hline Picrasmalignan A & $\begin{array}{l}\text { Reduce NO, TNF- } \alpha \text { and IL- } 6 \text { production and } \\
\text { up-regulation iNOS and COX-2 expression }\end{array}$ & $(44)$ \\
\hline
\end{tabular}

Modern clinical research indicated that $P$. quassioides has a significant effect on hypertension (32), pneumonia $(67,88)$, dysentery (89) and other disease symptoms $(90,91)$. Previous studies have also developed various preparations and drugs using P. quassioides, such as Kumu injection, Xiaoyan Lidan tablet (92), Fufang Kumu Xiaoyan capsule (93) and Fufang Kumu Xiaoyan tablet (94). Thus, use of $P$. quassioides in clinical settings has been gaining considerable attention.
P. quassioides also has an antivenom effect. P. quassioides is recorded for the treatment of snake venom poisoning in the Chinese Pharmacopoeia. Furthermore, clinical experiments suggested that Kumu injections impart a strong protective effect on mice and dogs poisoned by silver ring snake venom. In addition, Kumu injections had a protective effect against five-step snake (Hydrophis platurus) and cobra (Ophiophagus hannah) venom in canines, but not in poisoned 
Table VII. Role of active components of P. quassioides.

\begin{tabular}{|c|c|c|c|}
\hline Active component & Anti-inflammatory & Anti-cancer & Neuroinflammatory \\
\hline$\beta$-carboline alkaloids & $\begin{array}{l}\text { 6-methoxy-3-vinyl- } \beta \text {-carboline (27) } \\
\text { 6,12-dimethoxy-3-vinyl- } \beta \text { - } \\
\text { carboline (27), } \\
\text { 3-methylcanthin-5,6-dione (29), } \\
\text { 1-ethyl-1,2,3,4-tetrahydro- } \beta \text { - } \\
\text { carboline-3-carboxylic acid (30), } \\
\text { 1-acetophenone-1,2,3,4-tetrahydro- } \\
\beta \text {-carboline-3-carboxylic acid (30) }\end{array}$ & $\begin{array}{l}\text { 4-methoxy-1-vinyl- } \\
\beta \text {-carboline (67), } \\
1 \text {-methoxy- } \beta \text {-carboline (67), } \\
\beta \text {-carboline-1-carboxylic acid (68) }\end{array}$ & $\begin{array}{l}\text { 7-(4,4,4-trifluorobutoxy)- } \\
\text { 1-methyl- } \beta \text {-carboline (77), } \\
\text { 7-(cyclohexylmethoxy)- } \\
\text { 1-methyl- } \beta \text {-carboline ( } 83)\end{array}$ \\
\hline Arthinone alkaloids & $\begin{array}{l}\text { 4-methoxy-5-hydroxycanthin-6- } \\
\text { one (31), cathin-6-one }(30,34,35) \text {, } \\
\text { 9-methoxy-cathin-6-one }(30,33) \text {, } \\
\text { 1:4-methoxy-5-hyroxycanthin-6- } \\
\text { one (32), 4-methoxy-5- } \\
\text { hydroxycanthin 6-one (31), } \\
\text { 4-methoxycanthin-6-one (34), } \\
\text { picrasidine L (36), }\end{array}$ & $\begin{array}{l}\text { 9-methoxy-canthin-6-one (69) } \\
\text { canthin-6-one (69), } \\
\text { 4,5-dimethoxy-10-hydroxy- } \\
\text { canthin-6-one (70), } \\
\text { canthin-6-one alkaloids (70), } \\
\text { 8-hydroxy-canthin-6-one (70), } \\
\text { 4,5-dimethoxy-canthin-6-one (70), } \\
\text { 5-hydroxy-4-methoxycanthin-6- } \\
\text { one (70) }\end{array}$ & $\begin{array}{l}\text { Picrasidine } O(84), \\
\text { canthin-6-one }(85), \\
\text { 5-methoxycanthin- } \\
\text { 6-one }(85)\end{array}$ \\
\hline $\begin{array}{l}\text { Bis- } \beta \text {-carboline } \\
\text { alkaloids }\end{array}$ & $\begin{array}{l}\text { Quassidine } A(38), \\
\text { quassidine } E(39), \\
\text { quassidine } \mathrm{G}(39), \\
\text { quassidine } \mathrm{F}(39,27), \\
\text { picrasidine } \mathrm{C}(40), \\
\text { picrasidine } \mathrm{N}(40,41), \\
\text { picrasmalignan } \mathrm{A}(44)\end{array}$ & $\begin{array}{l}\text { B-9-3 (a new bimolecular } \\
\text { compound) ( } 71 \text { ), quassidines I ( } 72) \text {, } \\
\text { quassidines } \mathrm{J}(72) \text {, } \\
\text { picrasidine G ( } 73 \text { ) }\end{array}$ & - \\
\hline Triterpenoids & - & Kumuquassin C (74) & \\
\hline Quassinoids & - & - & $\begin{array}{l}\text { Picrasin } \mathrm{B}(86), \\
\text { nigakilactone F (86) }\end{array}$ \\
\hline
\end{tabular}

mice (3). Furthermore, the effect of Kumu injections on other snake venoms remains to be studied.

$P$. quassioides has antimalarial effects; 6-hydroxy-4methoxyl-1-vinyl- $\beta$-carboline extracted from the $P$. quassioides stem and bark inhibited the proliferation of the drug-resistant Fusarium protozoan. The cyclohexane extract of $P$. quassioides has strong antimalarial activity (95), which may be due to the antimalarial effect of nigakilactone in P. quassioides (96).

Quassinoids extracted from the P. quassioides stem may also be used as a stomachic agent and promote appetite when ingested in small amounts. However, excessive use may cause nausea. Nigakinone and methylnigakinone isolated from the methanolic extract of $P$. quassioides prevents the secretion of gastric juice in a dose-dependent manner and protects the gastric mucosa from potential side effects. Canthinone alkaloids and $\beta$-carboline alkaloids inhibited cAMP phosphodiesterase activity by accelerating blood flow in the gastrointestinal tract of rabbits. Thus, $P$. quassioides extracts have potential for treating stomach-related diseases $(97,98)$.

However, $P$. quassioides compounds have a certain degree of cytotoxicity due to their the cold property of drug (according to the concepts of Korean/Asian medicine). Overdose of these compounds may cause coldness in the spleen and stomach. In more serious cases, vomiting, diarrhea, dizziness, convulsions and other symptoms may occur and may even cause death (99). Therefore, it is necessary to monitor the dosing of these compounds and they should be ingested only after proper consultation with a doctor.

\section{Conclusions}

Chemical studies on plants of the Picrasma BL family indicated that alkaloids and quassinoids may be the major components contained in $P$. quassioides. Most of these alkaloids have parent $\beta$-carboline and canthin rings. Quassin may be a tetracyclic diterpene lactone component. In general, $P$. quassioides extracts and isolated compounds have good anti-inflammatory, antibacterial, antitumor and neuroprotective activities, while also having beneficial effects on the digestive system, heat removal and detoxification.

\section{Acknowledgements}

Not applicable. 


\section{Funding}

The present study was supported by the Basic Science Research Program through the National Research Foundation of Korea funded by the Ministry of Education (grant no. 2020R1I1A2052417) and The Korean Research Institute of Bioscience and Biotechnology Research Information System (grant no. RBM0112112).

\section{Availability of data and materials}

Not applicable.

\section{Authors' contributions}

JL, YXG, HNS and TK conceptualized the study, performed the literature search, collected and analyzed data and wrote the manuscript. HJ, HS and DPX performed the literature search and analyzed data. HNS and TK performed the literature review and revised the manuscript. All authors have read and approved the final manuscript. Data authentication is not applicable.

\section{Ethics approval and consent to participate}

Not applicable.

\section{Patient consent for publication}

Not applicable.

\section{Competing interests}

The authors declare that they have no competing interests.

\section{References}

1. National Pharmacopoeia Committee. Pharmacopoeia of the people's Republic of China, volume I (2010 edition), pp186, 2010.

2. Jiao WH, Gao H, Zhao F, Lin HW, Pan YM, Zhou GX and Yao XS: Anti-inflammatory alkaloids from the stems of Picrasma quassioides BENNET. Chem Pharm Bull (Tokyo) 59: 359-364, 2011

3. Liang WF: Anti-snake bite action of Picrasma quassioides. Zhong Yao Tong Bao 12: 54, 1987 (In Chinese).

4. Mohd Jamil MDH, Taher M, Susanti D, Rahman MA and Zakaria ZA: Phytochemistry, traditional use and pharmacological activity of Picrasma quassioides: A critical reviews. Nutrients 12: 2584, 2020

5. Jung YS, Eun CS, Jung YT, Kim HJ and $\mathrm{Yu} \mathrm{MH}$ Anti-inflammatory effects of Picrasma quassioides (D. DON) BENN leaves extracts. J Life Sci 23: 629-636, 2013.

6. Liu C, Cheng RR, Yang L, Song ZC and Wang ZT: Inhibition of CYP450 enzymes by quassinoids from Picrasma quassioides leaves. Phytochem Lett 30: 138-142, 2019.

7. Jiao WH, Gao H, Li CY, Zhou GX, Kitanaka S, Ohmura A and Yao XS: Beta-carboline alkaloids from the stems of Picrasma quassioides. Magn Reson Chem 48: 490-495, 2010.

8. Sung Y, Koike K, Nikaido T, Ohmoto T and Sankawa U: Inhibitors of cyclic AMP phosphodiesterase in Picrasma quas sioides Bennet, and inhibitory activities of related beta-carboline alkaloids. Chem Pharm Bull (Tokyo) 32: 1872-1877, 1984.

9. Zhao WY, Song XY, Zhao L, Zou CX, Zhou WY, Lin B, Yao GD, Huang XX and Song SJ: Quassinoids from Picrasma quassioides and their neuroprotective effects. J Nat Prod 82: 714-723, 2019.
10. Xu J, Xiao D, Lin QH, He JF, Liu WY, Xie N, Feng F and Qu W: Cytotoxic tirucallane and apotirucallane triterpenoids from the stems of Picrasma quassioides. J Nat Prod 79: 1899-1910, 2016.

11. Aggarwal NR, King LS and D'Alessio FR: Diverse macrophage populations mediate acute lung inflammation and resolution. Am J Physiol Lung Cell Mol Physiol 306: L709-L725, 2014.

12. Fahy JV: Type 2 inflammation in asthma-present in most, absent in many. Nat Rev Immunol 15: 57-65, 2015.

13. Lontchi-Yimagou E, Sobngwi E, Matsha TE and Kengne AP: Diabetes mellitus and inflammation. Curr Diab Rep 13: 435-444, 2013.

14. Agita A and Alsagaff MT: Inflammation, immunity, and hypertension. Acta Med Indones 49: 158-165, 2017.

15. Mason A, Holmes C and Edwards CJ: Inflammation and dementia: Using rheumatoid arthritis as a model to develop treatments? Autoimmun Rev 17: 919-925, 2018.

16. Taleb S: Inflammation in atherosclerosis. Arch Cardiovasc Dis 109: 708-715, 2016.

17. Fonceca AM, Zosky GR, Bozanich EM, Sutanto EN, Kicic A McNamara PS, Knight DA, Sly PD, Turner DJ and Stick SM: Accumulation mode particles and LPS exposure induce TLR-4 dependent and independent inflammatory responses in the lung. Respir Res 19: 15, 2018.

18. Olmos-Ortiz A, Déciga-García M, Preciado-Martínez E, Bermejo-Martínez L, Flores-Espinosa P, Mancilla-Herrera I, Irles C, Helguera-Repetto AC, Quesada-Reyna B, Goffin V, et al: Prolactin decreases LPS-induced inflammatory cytokines by inhibiting TLR-4/NF $\mathrm{KB}$ signaling in the human placenta. Mol Hum Reprod 25: 660-667, 2019.

19. Lai JL, Liu YH, Liu C, Qi MP, Liu RN, Zhu XF, Zhou QG, Chen YY, Guo AZ and Hu CM: Indirubin inhibits LPS-induced inflammation via TLR4 abrogation mediated by the NF- $\kappa \mathrm{B}$ and MAPK signaling pathways. Inflammation 40: 1-12, 2017.

20. Yu Q, Zeng K, Ma X, Song F, Jiang Y, Tu P and Wang X: Resokaempferol-mediated anti-inflammatory effects on activated macrophages via the inhibition of JAK2/STAT3, NF- $\mathrm{BB}$ and JNK/p38 MAPK signaling pathways. Int Immunopharmacol 38: 104-114, 2016.

21. Kwon MY, Park J, Kim SM, Lee J, Cho H, Park JH and Han IO: An alpha-lipoic acid-decursinol hybrid compound attenuates lipopolysaccharide-mediated inflammation in BV2 and RAW264.7 cells. BMB Rep 52: 508-513, 2019.

22. Liang $M$, Wang $X$, Yuan $Y$, Zhou Q, Tong $C$ and Jiang W: Different effect of glutamine on macrophage tumor necrosis factor-alpha release and heat shock protein 72 expression in vitro and in vivo. Acta Biochim Biophys Sin (Shanghai) 41: 171-177, 2009.

23. Balkwill F: TNF-alpha in promotion and progression of cancer. Cancer Metastasis Rev 25: 409-416, 2006.

24. Floros T and Tarhini AA: Anticancer cytokines: Biology and clinical effects of interferon- $\alpha 2$, interleukin (IL)-2, IL-15, IL-21, and IL-12. Semin Oncol 42: 539-548, 2015.

25. Nagayama M, Niwa K, Nagayama T, Ross ME and Iadecola C: The cyclooxygenase-2 inhibitor NS-398 ameliorates ischemic brain injury in wild-type mice but not in mice with deletion of the inducible nitric oxide synthase gene. J Cereb Blood Flow Metab 19: 1213-1219, 1999.

26. Shin NR, Shin IS, Jeon CM, Hong JM, Oh SR, Hahn KW and Ahn KS: Inhibitory effects of Picrasma quassioides (D. Don) Benn. On airway inflammation in a murine model of allergic asthma. Mol Med Rep 10: 1495-1500, 2014.

27. Zhao F, Gao Z, Jiao W, Chen L, Chen L and Yao X: In vitro anti-inflammatory effects of beta-carboline alkaloids, isolated from Picrasma quassioides, through inhibition of the iNOS pathway. Planta Med 78: 1906-1911, 2012.

28. Wirtz S, Popp V, Kindermann M, Gerlach K, Weigmann B, Fichtner-Feigl S and Neurath MF: Chemically induced mouse models of acute and chronic intestinal inflammation. Nat Protoc 12: 1295-1309, 2017.

29. Zhao W, He J, Zhang Y, Ito Y, Su Q and Sun W: Preparative isolation and purification of alkaloids from Picrasma quassioides (D. Don) Benn. By high-speed countercurrent chromatography. J Liq Chromatogr Relat Technol 35: 1597-1606, 2012.

30. Liu P, Li H, Luan R, Huang G, Liu Y, Wang M, Chao Q, Wang L, Li D, Fan $\mathrm{H}$, et al: Identification of $\beta$-carboline and canthinone alkaloids as anti-inflammatory agents but with different inhibitory profile on the expression of iNOS and COX-2 in lipopolysaccharide-activated RAW 264.7 macrophages. J Nat Med 73: 124-130, 2019. 
31. Fan H, Qi D, Yang M, Fang H, Liu K and Zhao F: In vitro and in vivo anti-inflammatory effects of 4-methoxy-5-hydroxycanthin-6-one, a natural alkaloid from Picrasma quassioides. Phytomedicine 20: 319-323, 2013.

32. Zhao W, Yu J, Su Q, Liang J, Zhao L, Zhang Y and Sun W: Antihypertensive effects of extract from Picrasma quassioides (D. Don) Benn. In spontaneously hypertensive rats. J Ethnopharmacol 145: 187-192, 2013.

33. Liu JF, Shao M, Zhai DW, Liu K and Wu LJ: Protective effect of 4-methoxy-5-hydroxycanthin-6-one, a natural alkaloid, on dextran sulfate sodium-induced rat colitis. Planta Med 75 142-145, 2009

34. Noldin VF, de Oliveira Martins DT, Marcello CM, da Silva Lima JC, Delle Monache F and Cechinel Filho V: Phytochemical and antiulcerogenic properties of rhizomes from Simaba ferruginea St. Hill. (Simaroubaceae). Z Naturforsch C J Biosci 60: 701-706, 2005.

35. de Souza Almeida ES, Filho VC, Niero R, Clasen BK, Balogun SO and de Oliveira Martins DT: Pharmacologica mechanisms underlying the anti-ulcer activity of methanol extract and canthin-6-one of Simaba ferruginea A. St-Hil. in animal models. J Ethnopharmacol 134: 630-636, 2011.

36. Sasaki T, Li W, Higai K and Koike K: Canthinone alkaloids are novel protein tyrosine phosphatase $1 \mathrm{~B}$ inhibitors. Bioorg Med Chem Lett 25: 1979-1981, 2015.

37. Ono H: Molecular mechanisms of hypothalamic insulin resistance. Int J Mol Sci 20: 1317, 2019.

38. Legrand N, Bretscher CL, Zielke S, Wilke B, Daude M, Fritz B, Diederich WE and Adhikary T: PPAR $\beta / \delta$ recruits NCOR and regulates transcription reinitiation of ANGPTL4. Nucleic Acids Res 47: 9573-9591, 2019.

39. Jiao WH, Gao H, Li CY, Zhao F, Jiang RW, Wang Y, Zhou GX and Yao XS: Quassidines A-D, bis-beta-carboline alkaloids from the stems of Picrasma quassioides. J Nat Prod 73: 167-171, 2010

40. Zhao S, Kanno Y, Li W, Sasaki T, Zhang X, Wang J, Cheng M, Koike K, Nemoto K and Li H: Identification of picrasidine C as a subtype-selective PPAR $\alpha$ agonist. J Nat Prod 79: 3127-3133, 2016.

41. Zhao S, Kanno Y,Li W, Wakatabi H, Sasaki T, Koike K, Nemoto K and $\mathrm{Li} \mathrm{H}$ : Picrasidine $\mathrm{N}$ Is a subtype-selective PPAR $\beta / \delta$ agonist. J Nat Prod 79: 879-885, 2016.

42. Chong HC, Chan JS, Goh CQ, Gounko NV, Luo B, Wang X, Foo S, Wong MT, Choong C, Kersten S and Tan NS: Angiopoietin-like 4 stimulates STAT3-mediated iNOS expression and enhances angiogenesis to accelerate wound healing in diabetic mice. Mol Ther 22: 1593-1604, 2014.

43. Georgiadi A, Wang Y, Stienstra R, Tjeerdema N, Janssen A, Stalenhoef A, van der Vliet JA, de Roos A, Tamsma JT, Smit JW, et al: Overexpression of angiopoietin-like protein 4 protects against atherosclerosis development. Arterioscler Thromb Vasc Biol 33: 1529-1537, 2013

44. Zhao F, Chen L, Bi C, Zhang M, Jiao $\mathrm{W}$ and Yao X: In vitro anti-inflammatory effect of picrasmalignan $\mathrm{A}$ by the inhibition of iNOS and COX-2 expression in LPS-activated macrophage RAW 264.7 cells. Mol Med Rep 8: 1575-1579, 2013

45. Jemal A, Center MM, DeSantis C and Ward EM: Global patterns of cancer incidence and mortality rates and trends. Cancer Epidemiol Biomarkers Prev 19: 1893-1907, 2010.

46. Subramani R, Nandy SB, Pedroza DA and Lakshmanaswamy R: Role of growth hormone in breast cancer. Endocrinology 158 $1543-1555,2017$.

47. Takano T: Natural history of thyroid cancer (Review). Endocr J 64: 237-244, 2017

48. Pramesh CS, Mistry RC and Laskar SG: Neoadjuvant chemoradiotherapy in resectable oesophageal cancer. Lancet Oncol 6: 824-826, 2005.

49. Siddiqui NS, Godara A, Byrne MM and Saif MW: Capecitabine for the treatment of pancreatic cancer. Expert Opin Pharmacother 20: 399-409, 2019.

50. Suroowan S and Mahomoodally MF: Herbal medicine of the 21st century: A focus on the chemistry, pharmacokinetics and toxicity of five widely advocated phytotherapies. Curr Top Med Chem 19: 2718-2738, 2019.

51. Sun Y, Xun K, Wang Y and Chen X: A systematic review of the anticancer properties of berberine, a natural product from Chinese herbs. Anticancer Drugs 20: 757-769, 2009.

52. Sun W, Yu J, Gao H, Wu X, Wang S, Hou Y, Lu JJ and Chen X: Inhibition of lung cancer by 2-Methoxy-6-Acetyl-7-methyljuglone through induction of necroptosis by targeting receptor-interacting protein 1. Antioxid Redox Signal 31: 93-108, 2019.
53. Wang Q, Mo J, Zhao C, Huang K, Feng M, He W, Wang J, Chen S, Xie Z, Ma J and Fan S: Raddeanin A suppresses breast cancer-associated osteolysis through inhibiting osteoclasts and breast cancer cells. Cell Death Dis 9: 376, 2018.

54. Zang M, Hu L, Zhang B, Zhu Z, Li J, Zhu Z, Yan M and Liu B: Luteolin suppresses angiogenesis and vasculogenic mimicry formation through inhibiting notch1-VEGF signaling in gastric cancer. Biochem Biophys Res Commun 490: 913-919, 2017.

55. Yang S, Li X, Dou H, Hu Y, Che C and Xu D: Sesamin induces A549 cell mitophagy and mitochondrial apoptosis via a reactive oxygen species-mediated reduction in mitochondrial membrane potential. Korean J Physiol Pharmacol 24: 223-232, 2020.

56. Ni Y, Zhang H, Li Z and Li Z: Connective tissue growth factor (CCN2) inhibits TNF- $\alpha$-induced apoptosis by enhancing autophagy through the Akt and Erk pathways in osteoblasts. Pharmazie 75: 213-217, 2020.

57. Wang HF, Wang ZQ, Ding Y, Piao MH, Feng CS, Chi GF, Luo YN and Ge PF: Endoplasmic reticulum stress regulates oxygen-glucose deprivation-induced parthanatos in human SH-SY5Y cells via improvement of intracellular ROS. CNS Neurosci Ther 24: 29-38, 2018.

58. Matt S and Hofmann TG: The DNA damage-induced cell death response: A roadmap to kill cancer cells. Cell Mol Life Sci 73: 2829-2850, 2016

59. Liao NC, Shih YL, Chou JS, Chen KW, Chen YL, Lee MH, Peng SF, Leu SJ and Chung JG: Cardamonin induces cell cycle arrest, apoptosis and alters apoptosis associated gene expression in WEHI-3 mouse leukemia cells. Am J Chin Med 47: 635-656, 2019.

60. Sun Y, Liu WZ, Liu T, Feng X, Yang N and Zhou HF: Signaling pathway of MAPK/ERK in cell proliferation, differentiation, migration, senescence and apoptosis. J Recept Signal Transduct Res 35: 600-604, 2015.

61. Su D, Zhou Y,Hu S, Guan L, Shi C, Wang Q, Chen Y,Lu C,LiQ and Ma X: Role of GAB1/PI3K/AKT signaling high glucose-induced cardiomyocyte apoptosis. Biomed Pharmacother 93: 1197-1204, 2017.

62. Yang X, Tang S, Li D, Yu X, Wang F and Xiao X: DIDS inhibits overexpression BAK1-induced mitochondrial apoptosis through GSK3 $\beta / \beta$-catenin signaling pathway. J Cell Physiol 233: 5070-5077, 2018

63. Lee HE, Choi ES, Shin JA, Kim LH, Cho NP and Cho SD Apoptotic effect of methanol extract of Picrasma quassioides by regulating specificity protein 1 in human cervical cancer cells. Cell Biochem Funct 32: 229-235, 2014.

64. Gong YX, Liu Y, Jin YH, Jin MH, Han YH, Li J, Shen GN, Xie DP, Ren CX, Yu LY, et al: Picrasma quassioides extract elevates the cervical cancer cell apoptosis through ROS-mitochondrial axis activated p38 MAPK signaling pathway. In Vivo 34: 1823-1833, 2020.

65. Xie DP, Gong YX, Jin YH, Ren CX, Liu Y, Han YH, Jin MH, Zhu D, Pan QZ, Yu LY, et al: Anti-tumor properties of Picrasma quassioides extracts in $\mathrm{H}-\mathrm{Ras}^{\mathrm{G} 12 \mathrm{~V}}$ liver cancer are mediated through ROS-dependent mitochondrial dysfunction. Anticancer Res 40: 3819-3830, 2020.

66. Xiao X, Si X, Tong X and Li G: Ultrasonic microwave-assisted extraction coupled with high-speed counter-current chromatography for the preparation of nigakinones from Picrasma quassioides (D. Don) Benn. Phytochem Anal 23: 540-546, 2012

67. Kwon HS, Lee H, Lee JS, Lee K, Choi JH and Jang DS: Two new $\beta$-carboline alkaloids from the stems of Picrasma quassioides. Arch Pharm Res 41: 513-518, 2018.

68. Lai ZQ, Liu WH, Ip SP, Liao HJ, Yi YY, Qin Z, Lai XP, Su ZR and Lin ZX: Seven alkaloids from Picrasma quassioides and their cytotoxic activities. Chem Nat Compd 50: 884-888, 2014.

69. Kuo PC, Shi LS, Damu AG, Su CR, Huang CH, Ke CH, Wu JB, Lin AJ, Bastow KF, Lee KH and Wu TS: Cytotoxic and antimalarial beta-carboline alkaloids from the roots of Eurycoma longifolia. J Nat Prod 66: 1324-1327, 2003.

70. Jiang MX and Zhou YJ: Canthin-6-one alkaloids from Picrasma quassioides and their cytotoxic activity. J Asian Nat Prod Res 10: 1009-1012, 2008.

71. Daoud A, Song J, Xiao F and Shang J: B-9-3, a novel $\beta$-carboline derivative exhibits anti-cancer activity via induction of apoptosis and inhibition of cell migration in vitro. Eur J Pharmacol 724: 219-230, 2014.

72. Jiao WH, Chen GD, Gao H, Li J, Gu BB, Xu TT, Yu HB, Shi GH, Yang F, Yao XS and Lin HW: ( \pm )-Quassidines I and J, two pairs of cytotoxic bis- $\beta$-carboline alkaloid enantiomers from Picrasma quassioides. J Nat Prod 78: 125-130, 2015 
73. Yamashita N, Kondo M, Zhao S, Li W, Koike K, Nemoto K and Kanno Y: Picrasidine G decreases viability of MDA-MB 468 EGFR-overexpressing triple-negative breast cancer cells through inhibition of EGFR/STAT3 signaling pathway. Bioorg Med Chem Lett 27: 2608-2612, 2017.

74. Zhao WY, Chen JJ, Zou CX, Zhang YY, Yao GD, Wang XB, Huang XX, Lin B and Song SJ: New tirucallane triterpenoids from Picrasma quassioides with their potential antiproliferative activities on hepatoma cells. Bioorg Chem 84: 309-318, 2019.

75. Guo E, Hu Y, Du T, Zhu H, Chen L, Qu W, Zhang J, Xie N Liu W, Feng F and Xu J: Effects of Picrasma quassioides and its active constituents on Alzheimer's disease in vitro and in vivo. Bioorg Chem 92: 103258, 2019.

76. Koe BK and Lebel LA: Contrasting effects of ethyl beta-carboline-3-carboxylate (beta CCE) and diazepam on cerebellar cyclic GMP content and antagonism of both effects by Ro 15-1788, a specific benzodiazepine receptor blocker. Eur J Pharmacol 90: 97-102, 1983.

77. File SE and Lister RG: Interactions of ethyl-betacarboline-3-carboxylate and Ro 15-1788 with CGS 8216 in an animal model of anxiety. Neurosci Lett 39: 91-94, 1983.

78. Manzoor S and Hoda N: A comprehensive review of monoamine oxidase inhibitors as anti-Alzheimer's disease agents: A review. Eur J Med Chem 206: 112787, 2020

79. Kumar MJ and Andersen JK: Perspectives on MAO-B in aging and neurological disease: Where do we go from here? Mol Neurobiol 30: 77-89, 2004.

80. Singh A, Kukreti R, Saso L and Kukreti S: Oxidative stress: A key modulator in neurodegenerative diseases. Molecules 24 1583,2019

81. Simpson DSA and Oliver PL: ROS generation in microglia: Understanding oxidative stress and inflammation in neurodegenerative disease. Antioxidants (Basel) 9: 743, 2020.

82. Kerr JS, Adriaanse BA, Greig NH, Mattson MP, Cader MZ, Bohr VA and Fang EF: Mitophagy and Alzheimer's disease: Cellular and molecular mechanisms. Trends Neurosci 40 : 151-166, 2017.

83. Reniers J, Robert S, Frederick R, Masereel B, Vincent S and Wouters J: Synthesis and evaluation of $\beta$-carboline derivatives as potential monoamine oxidase inhibitors. Bioorg Med Chem 19 134-144, 2011

84. Sasaki T, Li W, Ohmoto T and Koike K: Evaluation of canthinone alkaloids as cerebral protective agents. Bioorg Med Chem Lett 26: 4992-4995, 2016

85. Zhu C, Deng G and Lin C: Study on chemical constituents of Picrasma quassioides. Zhongguo Zhong Yao Za Zhi 36: 886-890, 2011 (In Chinese).

86. Matsuzaki T, Fukamiya N, Okano M, Fujita T, Tagahara K and Lee KH: Picrasinoside $\mathrm{H}$, a new quassinoid glucoside, and related compounds from the stem wood of Picrasma ailanthoides. J Nat Prod 54: 844-848, 1991.

87. He C, Wang Y, Yang T, Wang H, Liao H and Liang D: Quassinoids with insecticidal activity against diaphorina citri kuwayama and neuroprotective activities from Picrasma quassioides. J Agric Food Chem 68: 117-127, 2020.
88. Houël E, Stien D, Bourdy G and Deharo E: Quassinoids: anticancer and antimalarial activities. In: Natural Products: Phytochemistry, Botany and Metabolism of Alkaloids, Phenolics and Terpenes. Ramawat KG and Mérillon JM (eds). Berlin, Heidelberg: Springer Berlin Heidelberg, pp3775-3802, 2013.

89. Houël E, Bertani S, Bourdy G, Deharo E, Jullian V, Valentin A, Chevalley S and Stien D: Quassinoid constituents of Quassia amara L. leaf herbal tea. Impact on its antimalarial activity and cytotoxicity. J Ethnopharmacol 126: 114-118, 2009.

90. Niiho Y, Mitsunaga K, Koike K and Ohmoto T: Studies on the gastric antiulcer components from the woods of Picrasma quassioides (simaroubaceae). Nat Med 48: 116-121, 1994.

91. Teja Sri K, Bhargavi S, Ushasri S, Amareswara Reddy B and Geethika Priscilla M: Antiulcer herbal drugs-A compilation. Int J Uni Pharm Bio Sci 2: 285-297, 2013.

92. Huang X, Su Z, Shen X, Tang Q, Xie Y, Liu Z and Lai X: Determination of andrographolides and alkaloids in Xiaoyanlidan tablets by RP-HPLC. Chin Tradit Pat Med 6: 451-454, 2003.

93. Yang N, Xiong A, Wang R, Yang L and Wang Z: Quality evaluation of traditional Chinese medicine compounds in Xiaoyan Lidan tablets: Fingerprint and quantitative analysis using UPLC-MS. Molecules 21: 83, 2016.

94. Renliu X: TLC identification and determination of deoxyandrographolide of compound kumuxiaoyan tablets. Chin Tradit Pat Med, 1992.

95. Saiin C, Rattanajak R, Kamchonwongpaisan S, Ingkaninan K, Sukontason K, Baramee A and Sirithunyalug B: Isolation and in vitro antimalarial activity of hexane extract from Thai Picrasma javanica B1 stembark. Southeast Asian J Trop Med Public Health 34 (Suppl 2): S51-S55, 2003.

96. Rahman S, Fukamiya N, Okano M, Tagahara K and Lee KH: Anti-tuberculosis activity of quassinoids. Chem Pharm Bull (Tokyo) 45: 1527-1529, 1997.

97. Ohmoto T, Nikaido T, Koike K, Kohda K and Sankawa U: Inhibition of adenosine 3',5'-cyclic monophosphate phosphodiesterase by alkaloids. II. Chem Pharm Bull (Tokyo) 36: 4588-4592, 1988.

98. Zhao L, Zhao Y, Guo L and Zhang L: Pharmacokinetic and bioavailability study of 5-hydroxy-4-methoxycanthin-6-one, a typical canthinone alkaloid, in rats using ultra-high performance liquid chromatography/electrospray ionization tandem mass spectrometry. Biomed Chromatogr 34: e4830, 2020.

99. Xuan YH, Jin Y, Row KH and Jin Y: Antioxidant and anticancer activities of extracts from Picrasma quassioides (D. Don) Benn. Asian J Chem 22: 7219-7226, 2010.

This work is licensed under a Creative Commons Attribution-NonCommercial-NoDerivatives 4.0 International (CC BY-NC-ND 4.0) License. 